\title{
Direct-acting Antiviral Agents in Patients with Chronic Hepatitis C: Real-life Data
}

\section{Kronik Hepatit C Hastalarında Direkt Etkili Antiviral Ajanlar: Gerçek Yașam Verileri}

\author{
(1) Ayhan Balkan1, (1) Yasemin Balkan², (1) Abdullah Emre Yıldıım¹, (1) Buğra Tolga Konduk1,

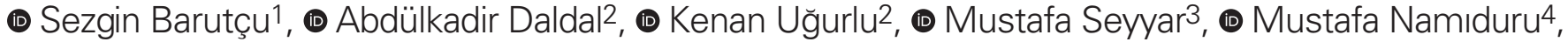 \\ - Taylan Metin ${ }^{3}$, ๑ Murat Taner Gülşen ${ }^{1}$ \\ ${ }^{1}$ Gaziantep University Faculty of Medicine, Department of Gastroenterology, Gaziantep, Turkey \\ ${ }^{2}$ Gaziantep 25 Aralık State Hospital, Clinic of Infectious Diseases and Clinical Microbiology, Gaziantep, Turkey \\ ${ }^{3}$ Gaziantep University Faculty of Medicine, Department of Internal Medicine, Gaziantep, Turkey \\ ${ }^{4}$ Gaziantep University Faculty of Medicine, Department of Infectious Diseases and Clinical Microbiology, Gaziantep, Turkey
}

\begin{abstract}
Objectives: In the treatment of chronic hepatitis $\mathrm{C}(\mathrm{CHC})$, very high rates of sustained virological response (SVR) have been obtained with direct-acting antivirals. In this study, we aimed to evaluate the efficacy and safety of therapies containing ledipasvir + sofosbuvir (Led + Sof), Sof, paritaprevir/ritonavir/ombitasvir + dasabuvir (PrOD) and PrO.

Materials and Methods: Three hundred patients with $\mathrm{CHC}$, who received Led + Sof, Sof, PrOD or PrO treatment were included in the study.

Results: One hundred two (34\%) of the patients were treatmentnaive patients and $198(66 \%)$ had undergone treatment. Cirrhosis was present in $70(23.3 \%)$ of the patients. Thirty-five $(11.7 \%)$ of the patients were with genotype 1a, $261(87 \%)$ were with genotype $1 \mathrm{~b}$, $1(0.3 \%)$ was with genotype $2 a, 2(0.7 \%)$ were with $3 a$ and $1(0.3 \%)$ was with genotype $4 a$. While the rate of SVR was $98 \%$ in patients receiving Led + Sof \pm ribavirin $(R)$, it was $100 \%$ in patients receiving $\mathrm{PrOD} \pm \mathrm{R}$. Cirrhosis was found to be the only factor affecting SVR. An adverse event was observed in $60(40.5 \%)$ of patients using PrOD or PrOD + R, and in 68 (44.7\%) of those using Led + Sof or Led + Sof + R.

Conclusion: In CHC patients, PrOD and Led + Sof treatments are effective and reliable treatments and shows promise.

Keywords: Chronic hepatitis C, direct-acting antiviral agents, real-life data
\end{abstract}

\section{ÖZ}

Amaç: Kronik hepatit $\mathrm{C}(\mathrm{KHC})$ tedavisinde direkt etkili antiviraller ile çok yüksek kalıcı virolojik yanıt (KVY) oranları elde edilmiştir. Bu çalışmada, hastalarda ledipasvir + sofosbuvir (Led + Sof), Sof, paritaprevir/ritonavir/ombitasvir + dasabuvir (PrOD) ve $\mathrm{PrO}$ içeren tedavilerin etkinliğinin ve güvenilirliğinin değerlendirilmesi amaçlanmıştır.

Gereç ve Yöntemler: Çalışmaya KHC'li Led + Sof, Sof, PrOD veya PrO tedavisi alan 300 hasta alındı.

Bulgular: Hastaların 102'si (\%34) naif hasta, 198'i (\%66) tedavi deneyimliydi. Hastaların 70 'inde $(\% 23,3)$ siroz mevcuttu. Hastaların $35^{\prime} i(\% 11,7)$ genotip $1 a, 261^{\prime} i(\% 87)$ genotip $1 b$, 1'i $(\% 0,3)$ genotip $2 a, 2$ 'si $(\% 0,7)$ 3a ve 1'i $(\% 0,3)$ genotip 4a olarak saptandı. Led + Sof \pm ribavirin (R) alan hastalarda KVY oranı \%98 saptanırken, PrOD \pm R alan hastalarda \%100 saptandı. Siroz, KVY'yi etkileyen tek faktör olarak saptandı. PrOD veya PrOD+R kullanan hastaların 60'ında $(\% 40,5)$, Led + Sof veya Led + Sof + R kullanan hastaların 68'inde $(\% 44,7)$ herhangi bir advers olay görüldü.

Sonuç: KHC hastalarında, PrOD ve Led + Sof tedavileri, etkin ve güvenilir tedaviler olup, umut vadetmektedir.

Anahtar Kelimeler: Kronik hepatit C, direkt etkili antiviral ajanlar, gerçek yaşam verileri

Balkan A, Balkan Y, Yıldırım AE, Konduk BT, Barutçu S, Daldal A, Uğurlu K, Seyyar M, Namıduru M, Metin T, Gülşen MT. Direct-acting Antiviral Agents in Patients with Chronic Hepatitis C: Real-life Data. Viral Hepat J. 2021;27:42-48.

This study were presented orally at the $14^{\text {th }}$ National Hepato Gastroenterology Congress and $5^{\text {th }}$ National Gastroenterology Surgery Congress 2017, April 5-8, Antalya, Turkey.

Address for Correspondence: Ayhan Balkan MD, Gaziantep University Faculty of Medicine, Department of Gastroenterology, Gaziantep, Turkey Phone: +90 5322182224 E-mail: drayhanbalkan@hotmail.com ORCID ID: orcid.org/0000-0002-6475-9847 Received: 06.11.2020 Accepted: 16.05.2021

${ }^{\odot}$ Copyright 2021 by Viral Hepatitis Society / Viral Hepatitis Journal published by Galenos Publishing House. 


\section{Introduction}

The prevalence of hepatitis $\mathrm{C}$ virus $(\mathrm{HCV})$ infection in the world is around $3 \%$. This indicates that an estimated $170-180$ million people are infected with HCV. Of all HCV cases, $42.2 \%$ are with genotype 1,30.1\% are with genotype 3, 9.1\% are with genotype $2,8.3 \%$ are with genotype $4,5.4 \%$ are with genotype 6 , and less than $1 \%$ are with genotype 5 (1). In terms of the HCV cases in Turkey, 66.7 to $100 \%$ of the patients are with genotype $1 \mathrm{~b}, 3.45$ to $33.7 \%$ are with genotype $1 \mathrm{a}$ and $3.7 \%$ are with genotype 4 (2).

$\mathrm{HCV}$ infection is a slowly progressive, insidious disease. The natural course of $\mathrm{HCV}$ infection differs among individuals. This difference is due to many factors that concern both virus and host (3). Clinical significance of liver disease associated with HCV involves the fact that $50-85 \%$ of the disease becomes chronic after acute infection and that cirrhosis develops in $2-20 \%$ of chronic cases after 20-30 years as well as presence of $1-4 \%$ risk for developing hepatocellular carcinoma (HCC) per year in cases with cirrhosis (4).

The primary goal of treatment in chronic hepatitis $\mathrm{C}(\mathrm{CHC})$ infection is to prevent liver necroinflammation, fibrosis, cirrhosis, HCC and extrahepatic findings by accomplishing eradication of HCV. Thus, the need for liver transplantation, morbidity and mortality is reduced $(5,6)$. Permanent response was confirmed in more than $98 \%$ of patients with negative HCV-RNA in serum during long-term follow-up studies in the $24^{\text {th }}$ week following the completion of the treatment (7). Even in patients with advanced fibrosis, significant reductions in liver-related deaths and hepatic decompensation can be observed after successful treatment $(8,9,10)$. In patients responding to treatment, a decrease in the incidence of HCC has been detected (11). It has been shown that life expectancy is prolonged in patients with advanced fibrosis and liver cirrhosis if SVR is achieved (12).

In this study, we aimed to evaluate the efficacy and safety of therapies containing ledipasvir/sofosbuvir (Led + Sof), Sof, paritaprevir/ritonavir/ombitasvir + dasabuvir (PrOD) and PrO.

\section{Materials and Methods}

\section{Patients}

Three hundred patients who admitted to Gaziantep University Faculty of Medicine Hospital, Hepatology and Infection Outpatient Clinic between June 2016 and December 2017 with a diagnosis of $\mathrm{CHC}$ and received Led + Sof, Sof, PrOD or PrO treatment were retrospectively included in the study.

The study was carried out in accordance with principles of the Helsinki Declaration of 1975 as revised in 2008, and with the approval number 08/05/2017/187 of the Gaziantep University Faculty of Medicine Clinical Research Ethics Committee. All patients provided written consent and study entry with all clinical investigations conducted according to the principles expressed in the Declaration of Helsinki.

\section{Methods}

Age, gender, body mass index (BMI) of patients, previous treatment experiences, responses to previous treatment, presence of cirrhosis, Child-Pugh score, HCV genotype, concomitant disease status, fibrosis staging of liver biopsies, treatment regimen, duration of treatment regimen, pre-treatment HCV-RNA level, complete blood count, biochemical parameters, international normalized ratio (INR) level and alpha fetoprotein (AFP) level were examined. HCV-RNA, complete blood count, biochemical parameters, INR level, AFP level, and side effects that occurred during treatment were evaluated on the $4^{\text {th }}$ and $8^{\text {th }}$ weeks of treatment, end of treatment and $12^{\text {th }}$ week after treatment. The efficacy and safety of treatments with direct-acting antiviral agents (DAA) were investigated. Patients were divided into two subgroups; those receiving $\mathrm{PrOD}$ or $\mathrm{PrO}$ and those receiving Led + Sof or Sof.

\section{Laboratory Testing}

Anti-HCV test is a two-step immunoassay and chemiluminescent microparticle immunoassay technique (Architect i1000, Abbott, USA) was studied. HCV-RNA measurement was performed using $\mathrm{COBAS}^{\circledR}$ AmpliPrep/COBAS ${ }^{\circledR}$ TaqMan $^{\circledR}$ HCV Quantitative v2.0 (Roche Molecular Diagnostics, USA) commercial kits according to the manufacturer's instructions. HCV-RNA genotyping was performed with sequence primers in the PyroMark O24 device.

\section{Statistical Analysis}

The compliance of the numerical data to the normal distribution was tested with the Shapiro-Wilk test. Student's t-test was used to compare variables that comply with normal distribution in 2 groups. The paired sample t-test was used to compare measurements of normally distributed dependent variables. The relationship between categorical variables was tested by chi-square test. SPSS 22.0 (SPSS Inc., Chicago, IL, USA) package program was used in the analysis. A p-value $\leq 0.05$ was considered statistically significant.

\section{Results}

Three hundred patients were included in this study. Ninetyseven $(32.3 \%)$ of the patients were male and 203 (67.7\%) were female. Thirty-five $(11.7 \%)$ of the patients were with genotype $1 \mathrm{a}$, $261(87 \%)$ were with genotype 1 b, $1(0.3 \%)$ was with genotype $2 a$, $2(0.7 \%)$ were with genotype $3 a$ and $1(0.3 \%)$ was with genotype 4a. The number of patients with cirrhosis was 70 (23.3\%). In terms of previous treatment experiences; 102 (34\%) of the patients were naive, $185(61.7 \%)$ received peginterferon alpha (Peg-IFN $\alpha)+$ ribavirin and $13(4.5 \%)$ received Peg-IFN $\alpha+$ ribavirin + first generation protease inhibitor (PI). Ninety-four of the patients $(31.3 \%)$ had at least one additional disease. Fifty patients (16.7\%) had diabetes, 16 (5.3\%) had chronic renal failure (CRF), 35 (11.7\%) had hypertension $(\mathrm{HT})$ and $3(1 \%)$ had hepatitis B virus (HBV) infection. The number of liver transplant patients was 10 (3.3\%). In terms of the DAA regimens received by patients; 12 patients (4\%) were given Led + Sof for 12 weeks, 112 (37.3\%) patients received Led + Sof for 24 weeks, 27 (9\%) patients received Led + Sof + $\mathrm{R}$ for 12 weeks, 1 (0.3\%) patient received Sof for 12 weeks, 139 (46.3\%) patients received PrOD for 12 weeks, 8 (2.7\%) patients received $\mathrm{PrOD}+\mathrm{R}$ for 12 weeks and 1 (0.3\%) patient received $\mathrm{PrO}+\mathrm{R}$ for 12 weeks. Ribavirin could not be administered to one patient with genotype $2 a$ who received the Sof regimen because the hemoglobin $(\mathrm{Hb})$ value of that patient was $8.6 \mathrm{~g} / \mathrm{dL}$. The demographic characteristics of the patients are shown in Table 1. 
Table 1. Demographic and clinical characteristics of the patients

\begin{tabular}{|c|c|}
\hline Patients & $\mathrm{n}(\%)$ \\
\hline Age & $61.65 \pm 9.76$ \\
\hline Diagnosis year & $9.32 \pm 3.92$ \\
\hline $\mathrm{BMI},\left(\mathrm{kg} / \mathrm{m}^{2}\right)$ & $27.72 \pm 4.22$ \\
\hline Gender, female & $203(67.7)$ \\
\hline \multicolumn{2}{|l|}{ Genotype } \\
\hline $1 \mathrm{~A}$ & $35(11.7)$ \\
\hline 1B & $261(87)$ \\
\hline $2 \mathrm{~A}$ & $1(0.3)$ \\
\hline $3 \mathrm{~A}$ & $2(0.7)$ \\
\hline $4 \mathrm{~A}$ & $1(0.3)$ \\
\hline Cirrhosis & $70(23.3)$ \\
\hline \multicolumn{2}{|l|}{ Child Pugh } \\
\hline A & $35(50)$ \\
\hline B & $26(37.1)$ \\
\hline C & 9 (12.9) \\
\hline \multicolumn{2}{|l|}{ Treatment experience } \\
\hline Naive & $102(34)$ \\
\hline Peg-IFN + R & $185(61.7)$ \\
\hline Peg-IFN + R + PI & $13(4.3)$ \\
\hline \multicolumn{2}{|l|}{ Treatment response } \\
\hline Relapse & $158(52.7)$ \\
\hline Partial response & $4(1.3)$ \\
\hline Unresponsive & $31(10.3)$ \\
\hline Stop treatment due to side effects & $6(2)$ \\
\hline \multicolumn{2}{|l|}{ Additional disease } \\
\hline CRF & $16(5.3)$ \\
\hline DM & $50(16.7)$ \\
\hline HT & $35(11.7)$ \\
\hline HBV & $3(1)$ \\
\hline Liver transplantation & $10(3.3)$ \\
\hline \multicolumn{2}{|l|}{ DAAs } \\
\hline Led + Sof 12 week & $12(4)$ \\
\hline Led + Sof 24 week & $112(37.3)$ \\
\hline Led + Sof + R 12 week & $27(9)$ \\
\hline Sof 12 week & $1(0.3)$ \\
\hline PrOD 12 week & $139(46.3)$ \\
\hline PrOD + R 12 week & $8(2.7)$ \\
\hline $\mathrm{PrO}+\mathrm{R} 12$ week & $1(0.3)$ \\
\hline \multicolumn{2}{|l|}{ Fibrosis } \\
\hline F1-2 & $32(23.8)$ \\
\hline F3-4 & $67(50)$ \\
\hline F5-6 & $35(26.2)$ \\
\hline \multicolumn{2}{|c|}{$\begin{array}{l}\text { BMI: Body mass index, Peg-IFN + R: Peginterferon + ribavirin, Peg-IFN + R } \\
+ \text { PI: Peginterferon + ribavirin + protease inhibitor, CRF: Chronic renal failure, } \\
\text { DM: Diabetes mellitus, HT: Hypertension, HBV: Hepatitis B virus, DAAs: Direct- } \\
\text { acting antiviral agents, Led + Sof: Ledipasvir + sofosbuvir, PrOD: Paritaprevir/ } \\
\text { ritonavir/ombitasvir + dasabuvir }\end{array}$} \\
\hline
\end{tabular}

The mean baseline HCV-RNA levels of the patients were $1,854,026 \pm 2,577,916 \mathrm{IU} / \mathrm{mL}$. The mean baseline AFP levels were $10 \pm 16.1 \mathrm{ng} / \mathrm{mL}$. The mean baseline alanine transaminase (ALT) and aspartate transaminase (AST) levels were $53.5 \pm 35 \mathrm{U} / \mathrm{L}$ and $58 \pm 38.6 \mathrm{U} / \mathrm{L}$, respectively. The mean baseline total bilirubin (TB) level was $1 \pm 0.9 \mathrm{mg} / \mathrm{dL}$. The mean baseline albumin level was $3.9 \pm 0.5 \mathrm{~g} / \mathrm{dL}$, whereas the mean baseline INR level was $1.1 \pm 0.5$. The mean baseline of creatinine was $1 \pm 0.7 \mathrm{mg} / \mathrm{dL}$. The mean baseline complete blood count parameters were as follows; white blood cell (WBC): $6.80 \pm 2.79 \times 10^{3} / \mu \mathrm{L}$, neutrophil: $3.74 \pm 1.70 \times 10^{3} / \mu \mathrm{L}$, lymphocyte: $2.06 \pm 1.00 \times 10^{3} / \mathrm{hL}, \mathrm{Hb}: 13.6 \pm 2 \mathrm{~g} / \mathrm{dL}$ and platelet (PLT): 194.77 $\pm 88.14 \times 10^{3} / \mu \mathrm{L}$ (Table 2).

Patients were divided into two groups in this study. Those who received Led + Sof for 12 weeks, Led + Sof for 24 weeks, Led + Sof + R for 12 weeks and Sof for 12 weeks were defined as Led + Sof $\pm R$ group, while those who received PrOD for 12 weeks, $\mathrm{PrOD}+\mathrm{R}$ for 12 weeks and $\mathrm{PrO}+\mathrm{R}$ for 12 weeks were defined as PrOD $\pm R$ group. Led + Sof $\pm R$ group consisted of 152 patients whereas PrOD $\pm \mathrm{R}$ consisted of 148 patients. When the virological response between the groups were assessed, there was no significant difference in the evaluation of the $4^{\text {th }}, 8^{\text {th }}$, end of treatment and $12^{\text {th }}$ week of SVR. In the $4^{\text {th }}$ week of treatment, HCV-RNA was negative in 135 (88.8\%) of patients receiving Led + Sof $\pm \mathrm{R}$ and in 133 (89.8\%) of patients receiving PrOD $\pm \mathrm{R}$. In the $8^{\text {th }}$ week of treatment, HCV-RNA was negative in $150(98.7 \%)$ of patients receiving Led + Sof $\pm R$ and 146 (98.6\%) of patients receiving $\operatorname{PrOD} \pm \mathrm{R}$. At the end of treatment, HCV-RNA was negative in all patients in both groups. While relapse was detected in 3 of the patients who received Led + Sof $\pm R$ at $12^{\text {th }}$ weeks, HCV-RNA negativity persisted in all patients who received PrOD $\pm \mathrm{R}$ (Figure 1).

Two of the patients who had relapse received Led + Sof for 24 weeks and one received Led + Sof for 12 weeks. Two of the patients were male and one was female. Patient 1 was 54 years old, patient 2 was aged 61, and patient 3 was aged 41 . When the genotype was examined, patient 1 was with $1 \mathrm{~b}$, patient 2 was with $1 \mathrm{a}$ and patient 3 was with 3a. Patient 1's HCV-RNA level was

\begin{tabular}{|l|l|}
\hline \multicolumn{2}{|l|}{ Table 2. Initial laboratory characteristics of the patients } \\
\hline HCV-RNA (IU/mL) & $1854026 \pm 2577916$ \\
\hline AFP $(\mathrm{ng} / \mathrm{mL})$ & $10 \pm 16.1$ \\
\hline ALT $(\mathrm{U} / \mathrm{L})$ & $53.5 \pm 35$ \\
\hline AST $(\mathrm{U} / \mathrm{L})$ & $58 \pm 38.6$ \\
\hline Total bilirubin $(\mathrm{mg} / \mathrm{dL})$ & $1 \pm 0.9$ \\
\hline Albumin $(\mathrm{g} / \mathrm{dL})$ & $3.9 \pm 0.5$ \\
\hline INR & $1.1 \pm 0.5$ \\
\hline Creatinine $(\mathrm{mg} / \mathrm{dL})$ & $1 \pm 0.7$ \\
\hline WBC $\left(\times 10^{3} / \mu \mathrm{L}\right)$ & $6.80 \pm 2.79$ \\
\hline Neutrophil $\left(\times 10^{3} / \mu \mathrm{L}\right)$ & $3.74 \pm 1.70$ \\
\hline Lymphocyte $\left(\times 10^{3} / \mu \mathrm{L}\right)$ & $2.06 \pm 1.00$ \\
\hline Hemoglobin $(\mathrm{g} / \mathrm{dL})$ & $13.6 \pm 2$ \\
\hline Thrombocyte $\left(\times 10^{3} / \mu \mathrm{L}\right)$ & $194.77 \pm 88.14$ \\
\hline $\begin{array}{l}\text { HCV: Hepatitis C virus, AFP: Alpha fetoprotein, ALT: Alanine } \\
\text { transaminase, AST: Aspartate transaminase, } \\
\text { cell, INR: International normalized ratio }\end{array}$ \\
\hline
\end{tabular}




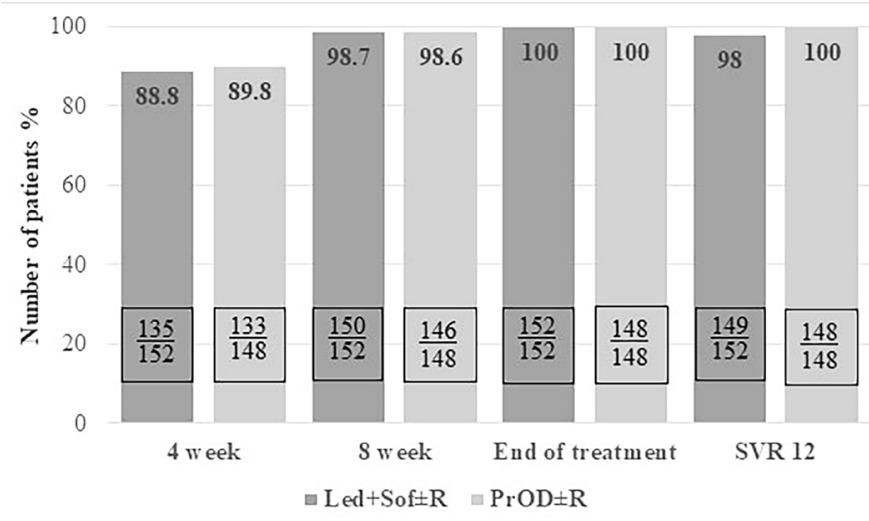

Figure 1. Response to treatment rates

Led + Sof: Ledipasvir + sofosbuvir, SVR: Sustained viral response, PrOD: Paritaprevir/ritonavir/ombitasvir + dasabuvir

$163,000 \mathrm{IU} / \mathrm{mL}$, patient 2's was 1,200,000 IU/mL, and patient 3's was 1,700,000 IU/mL. Two patients had cirrhosis, while one did not. According to the Child-Pugh classification, patient 1 was $B$ and patient 2 was C. One patient had received Peg-IFN $\alpha+$ ribavirin before, while the other two were naive. While patient 1 had $\mathrm{HT}$ and $\mathrm{CRF}$, patient 2 and patient 3 had no additional disease.

Factors affecting SVR are examined in Table 3. These factors included age, gender, BMI, HCV-RNA level, genotype, presence of cirrhosis, previous treatment experience, $\mathrm{CRF}$, diabetes mellitus, $\mathrm{HT}$, $\mathrm{HBV}$, newly received treatment and use of ribavirin. Among these, the only factor affecting SVR was the presence of cirrhosis and a significant relationship was found $(p=0.013)$.

In treatment groups, the change between baseline TB levels and levels in the $4^{\text {th }}$ week, $8^{\text {th }}$ week of treatment end-of-treatment, and SVR $12^{\text {th }}$ week were examined. There was a significant increase in TB levels in the 8th week of treatment in the PrOD group. However, there was a significant decrease in TB levels in the $12^{\text {th }}$ week of SVR in both groups.

In treatment groups, the change between the baseline $\mathrm{Hb}$ levels and the $4^{\text {th }}$ week, $8^{\text {th }}$ week of treatment, end-of-treatment and SVR $12^{\text {th }}$ week was examined.

The relationship between mean ALT, AST, TB, albumin, INR, PLT and $\mathrm{Hb}$ levels and SVR $12^{\text {th }}$ week levels in all patients were examined. Significant decreases were observed in AST, ALT and TB levels in the $12^{\text {th }}$ week of SVR, while significant increases were observed in albumin levels and PLT counts. No significant change was observed in $\mathrm{Hb}$ and INR Levels.

In terms of the side effects occurring in patients, the most common side effect in both groups was pruritus, insomnia and weakness. Side effects that would require discontinuation of treatment were seen in $2(1 \%)$ patients. Both patients were in the group receiving $\operatorname{PrOD} \pm R$ and the treatment was terminated at the $8^{\text {th }}$ week due to the grade 3 TB elevation. HCV-RNA was negative in both patients at the $12^{\text {th }}$ week of SVR. There was no significant difference between the groups in terms of itching, insomnia and weakness. Nausea was seen in $14(9.2 \%)$ of patients receiving Led + Sof $\pm R$, in $5(3.4 \%)$ of patients receiving PrOD $\pm R$ and difference was statistically significant $(p=0.038)$. Grade 2 anemia $(\mathrm{Hb}: 8-10 \mathrm{~g} / \mathrm{dL})$ occurred in $2(1.3 \%)$ of patients receiving Led
Table 3. Evaluation of the factors affecting the sustained virological response

\begin{tabular}{|c|c|c|}
\hline Patient characteristics & SVR, n (\%) & $p$ \\
\hline \multicolumn{3}{|l|}{ Age group } \\
\hline Over 65 & $117(100)$ & \multirow{2}{*}{0.084} \\
\hline Under 65 & $180(98.4)$ & \\
\hline \multicolumn{3}{|l|}{ Gender } \\
\hline Male & $95(98)$ & \multirow{2}{*}{0.221} \\
\hline Female & $202(99.3)$ & \\
\hline \multicolumn{3}{|l|}{ BMI, $\left(\mathrm{kg} / \mathrm{m}^{2}\right)$} \\
\hline$<25$ & $69(98.5)$ & \multirow{3}{*}{0.801} \\
\hline $25-30$ & $156(99.4)$ & \\
\hline$>30$ & $72(98.6)$ & \\
\hline \multicolumn{3}{|l|}{ HCV-RNA (IU/mL) } \\
\hline$>800,000$ & $166(98.8)$ & \multirow{2}{*}{0.705} \\
\hline$<800,000$ & $131(99.2)$ & \\
\hline \multicolumn{3}{|l|}{ Genotype } \\
\hline $1 \mathrm{~A}$ & $34(97.1)$ & \multirow{5}{*}{0.071} \\
\hline $1 \mathrm{~B}$ & $260(99.6)$ & \\
\hline $2 \mathrm{~A}$ & $1(100)$ & \\
\hline $3 A$ & $1(50)$ & \\
\hline $4 \mathrm{~A}$ & $1(100)$ & \\
\hline \multicolumn{3}{|c|}{ Treatment experience } \\
\hline Naive & $100(99)$ & \multirow{3}{*}{0.478} \\
\hline Peg-IFN + R & $184(99.4)$ & \\
\hline Peg-IFN + R + PI & $13(100)$ & \\
\hline \multicolumn{3}{|l|}{ Additional disease } \\
\hline Cirrhosis & $42(97.1)$ & $0.013^{*}$ \\
\hline CRF & $15(93.7)$ & 0.129 \\
\hline DM & $50(100)$ & 0.294 \\
\hline HT & $34(97.1)$ & 0.320 \\
\hline HBV & $3(100)$ & 0.806 \\
\hline The use of ribavirin & $36(100)$ & 0.380 \\
\hline \multicolumn{3}{|l|}{ Treatment regimen } \\
\hline Led + Sof $\pm R$ & $149(98)$ & \multirow{2}{*}{0.055} \\
\hline $\operatorname{PrOD} \pm \mathrm{R}$ & $148(100)$ & \\
\hline \multicolumn{3}{|c|}{$\begin{array}{l}\text { *: Statistically significant, SVR: Sustained viral response, BMI: Body mass } \\
\text { index, Peg-IFN + R: Peginterferon + ribavirin, Peg-IFN + R + PI: Peginterferon + } \\
\text { ribavirin + protease inhibitor, CRF: Chronic renal failure, DM: Diabetes mellitus, } \\
\text { HT: Hypertension, HBV: Hepatitis B virus, Led + Sof: Ledipasvir + sofosbuvir, } \\
\text { PrOD: Paritaprevir/ritonavir/ombitasvir + dasabuvir }\end{array}$} \\
\hline
\end{tabular}

+ Sof $\pm R$ and in $3(2 \%)$ of patients receiving PrOD $\pm R$, while grade 3 anemia $(\mathrm{Hb}:<8 \mathrm{~g} / \mathrm{dL}$ ) was not seen in either group and no significant relationship was found between the groups. Grade 2 TB elevation (1.5-3 fold increase) was seen in $3(2 \%)$ of patients receiving Led + Sof $\pm R$, and in $2(1.4 \%)$ of patients receiving PrOD $\pm R$. Grade 3 TB height ( $>3$ times) was not seen in Led + Sof \pm $R$ group, it was seen in $2(1.4 \%)$ of patients receiving PrOD $\pm R$. There was no significant relationship between groups with regard to TB elevation ( $p=0.333$ ) (Table 4). 


\begin{tabular}{|c|c|c|c|}
\hline & $\begin{array}{l}\text { Led }+ \text { Sof } \pm R \\
(n=152)(\%)\end{array}$ & $\begin{array}{l}\text { PrOD } \pm R \\
(n=148)(\%)\end{array}$ & $p$ \\
\hline $\begin{array}{l}\text { Any adverse } \\
\text { effects }\end{array}$ & $68(44.7)$ & $60(40.5)$ & 0.463 \\
\hline $\begin{array}{l}\text { Serious adverse } \\
\text { effects }\end{array}$ & $0(0)$ & $2(1.4)$ & 0.092 \\
\hline Itching & $42(27.6)$ & $27(18.2)$ & 0.053 \\
\hline Insomnia & $21(13.8)$ & $14(9.5)$ & 0.240 \\
\hline Weakness & $19(12.5)$ & $21(14.2)$ & 0.667 \\
\hline Nausea & $14(9.2)$ & $5(3.4)$ & $0.038^{*}$ \\
\hline Headache & $13(8.6)$ & $12(8.1)$ & 0.889 \\
\hline Anorexia & $14(9.2)$ & $9(6.1)$ & 0.308 \\
\hline \multicolumn{4}{|l|}{ Anemia } \\
\hline Grade 2 & $2(1.3)$ & $3(2)$ & \multirow{2}{*}{0.737} \\
\hline Grade 3 & $0(0)$ & $0(0)$ & \\
\hline \multicolumn{4}{|c|}{ Total bilirubin increase } \\
\hline Grade 2 & $3(2)$ & $2(1.4)$ & \multirow{2}{*}{0.333} \\
\hline Grade 3 & $0(0)$ & $2(1.4)$ & \\
\hline
\end{tabular}

\section{Discussion}

DAA are extremely important since they have very low rates of side effects as well as the SVR rates exceeding 95\%.

While HCV-RNA was negative in all patients at the end of the treatment, the rates of $12^{\text {th }}$ week of SVR were found to be $98 \%$ in the Led + Sof $\pm R$ group and $100 \%$ in the PrOD $\pm R$ group. The results of this study are consistent with studies previously performed in patients with CHC. In the study by Juanbeltz et al. (13), the $12^{\text {th }}$ week rate of SVR was $97.3 \%$ in all patients. When we look at the factors that affect SVR in our study, it was found that only the presence of cirrhosis was effective. The high number of patients with cirrhosis in the Led + Sof $\pm R$ group may be the reason that the rate of SVR is not $100 \%$ in this group.

In a study by Colombo et al. (14) in patients with genotype $1 \mathrm{~b}$, the $12^{\text {th }}$ week rate of SVR was $98.3 \%$ in the group who were with or without cirrhosis, naive or had previous treatment and received PrOD + R treatment. In the non-cirrhotic, naive or previously treated group receiving PrOD therapy, the $12^{\text {th }}$ week rate of SVR was $99.3 \%$ (14).

In the LONESTAR study, the $12^{\text {th }}$ week rate of SVR was $100 \%$ in the Led + Sof + R group and 95\% in the Led + Sof group (15). In our study, it was $100 \%$ in the Led + Sof + R group and $97.6 \%$ in the Led + Sof group.

In a study by Calleja et al. (16) in patients with genotype $1 \mathrm{~b}$, the $12^{\text {th }}$ week SVR rates were $91.7 \%$ in patients receiving Led + Sof for 8 weeks, $94.6 \%$ in patients receiving Led + Sof for 12 weeks, $98.0 \%$ in patients receiving PrOD for 12 weeks and $95.5 \%$ in patients receiving PrOD $+\mathrm{R}$ for 12 weeks (17). In our study, $12^{\text {th }}$ week SVR rates were $98.2 \%$ for patients receiving Led + Sof for 24 weeks, and $91.7 \%$ for those using Led + Sof 12 weeks, while it was $100 \%$ in other regimes.
In the study by Calleja et al. (16), $12^{\text {th }}$ week SVR rates were 95.8\% in Led + Sof $\pm R$ group and $96.8 \%$ in PrOD $\pm R$ group. Another point highlighted by the study is that rapid virological response (RVR) rates are low in patients receiving Led + Sof $\pm R$ (17). In the study by Backus et al. (18), it was found that RVR rates were low in similar rates. In our study, the rate of RVR was $88.8 \%$ in Led + Sof \pm R group and $89.8 \%$ in PrOD $\pm R$ group. Calleja et al. (17) stated that there is a significant relationship between cirrhosis status and RVR rate. They have shown that RVR rates are lower in the cirrhosis group. This was not noted in our study. Although the number of patients with cirrhosis was higher in Led + Sof $\pm R$ group, the rate of RVR was similar in both groups. However, it was assumed that cirrhosis might be effective in SVR rates.

loannou et al. (19), demonstrated that the SVR rates of Led + Sof and PrOD treatments without ribavirin were slightly higher, but this difference was not statistically significant. Regardless of the treatment regimens, the $12^{\text {th }}$ week SVR rates were $92.8 \%$ in all patients with genotype 1 . In our study, the $12^{\text {th }}$ week SVR was $98.8 \%$ in treatments without ribavirin and $100 \%$ in regimens with ribavirin. The $12^{\text {th }}$ week SVR rate in 296 patients with genotype 1 was $99.3 \%$

In a study with patients over 65 , the $12^{\text {th }}$ week SVR rate was $88.3 \%$ (20). Of these patients, 95\% were with genotype 1 and combinations of different DAAs, Led + Sof $\pm R$ and $\operatorname{PrOD} \pm R$, were given as the treatment regimen. In our study, there were 117 patients over 65 years of age and the $12^{\text {th }}$ week SVR rate was $100 \%$. It was predicted that the treatment regimens used in our study, especially for patients with genotype 1, did not require different combinations as they provide HCV-RNA negativity in all elderly patients.

In our study, at least one side effect was observed in 128 (42.7\%) of 300 patients. The most common side effect was itching followed by weakness, insomnia, headache, anorexia and nausea. Intergroup evaluation revealed that nausea was more common in Led + Sof $\pm R$ group and the difference was statistically significant. However, it was thought that this finding did not reflect an important condition because nausea was seen in very few patients. In the study by Welzel et al. (21), $42.7 \%$ of patients had at least one side effect. The rate of serious side effects in this study was $9.6 \%$, and the rate of drug cessation due to serious side effects was $6.8 \%$. Fatigue, itching and headache were the most common side effects. While the most common complaint in similar studies is weakness, we found itching as the most common side effect in our study. It should not be forgotten that ribavirin is present in treatment regimens, and any patient suffering from weakness should be evaluated for anemia and drug-related side effects.

In a multicenter study conducted by Calleja et al. (17) on patients with genotype 1, the rates of severe side effects and treatment discontinuation due to serious side effects were $5.5 \%$ and $1.5 \%$ in Led + Sof group, and $5.4 \%$ and $1.7 \%$ in PrOD group, respectively. Especially when evaluating the side effect, patients who do not receive ribavirin should be assessed with regard to anemia and TB elevation. In our study, 2 patients in the group receiving $\operatorname{PrOD} \pm \mathrm{R}$ could not complete the treatment because of the grade 3 TB elevation. One patient was receiving ribavirin while the other was not. Regardless of the treatment regimen, it was thought that AST, ALT, PLTS, WBC, albumin, INR and creatinine testing, especially $\mathrm{Hb}$ and $\mathrm{TB}$ values, were required. 
In the study by Rodríguez Osorio et al. (20) on 120 patients aged over 65 , the probability of side effects was $65 \%$. The majority of patients with side effects were those who received Pls. The most common side effects included weakness, anemia, itching and high bilirubin levels. This study suggests that the elevation of TB levels in our study group receiving $\operatorname{PrOD} \pm R$ may be related to the PI paritaprevir.

Since treatment regimens are given for 12 or 24 weeks, easy management of the side effects can be achieved. In addition, some studies show that treatment durations can be shortened to 4,6 or 8 weeks, depending on patient characteristics. Furthermore, SVR rates were found to be too high for patients who could not complete the treatment. In our study, although 2 patients stopped treatment after 8 weeks of treatment, HCV-RNA levels were negative in the $12^{\text {th }}$ week of SVR.

\section{Study Limitations}

The limitation of our study is that the study was a single center experience and only two types of drugs were used in the treatment.

\section{Conclusion}

The effectiveness of PrOD and Led + Sof combinations was close to $100 \%$ in patients with genotype 1 and it was assumed that HCV infection could be fully eradicated. Today, it should be remembered that antiviral treatment should be given in all patients with $\mathrm{CHC}$ infection and positive viral load, unless there are contraindications.

Acknowledgement: We thank the study investigators, coordinators, nurses, patients and their families for their contributions.

\section{Ethics}

Ethics Committee Approval: The study was carried out in accordance with principles of the Helsinki Declaration of 1975 as revised in 2008, and with the approval number 08/05/2017/187 of the Gaziantep University Faculty of Medicine Clinical Research Ethics Committee.

Informed Consent: All patients provided written consent and study entry with all clinical investigations conducted according to the principles expressed in the Declaration of Helsinki.

Peer-review: Externally and internally peer-reviewed.

\section{Authorship Contributions}

Medical Practices: A.B., M.S., T.M., M.T.G., Concept: A.B., Y.B., A.E.Y., B.T.K., S.B., Design: A.B., Y.B., A.E.Y., B.T.K., S.B., Data Collection or Processing: A.B., Y.B., A.E.Y., B.T.K., S.B., A.D., K.U., M.S., M.N., T.M., Analysis or Interpretation: A.B., M.S., T.M., Literature Search: A.B., M.S., T.M., Writing: A.B., M.S., T.M.

Conflict of interest: The authors declared that there was no conflict of interest.

Financial Disclosure: The authors declared that this study has received no financial support.

\section{References}

1. Messina JP, Humphreys I, Flaxman A, Brown A, Cooke Gs, Pybus Og, Barnes E. Global distribution and prevalence of hepatitis C virus genotypes. Hepatology. 2015;61:77-87.
2. Durmaz R. HCV mutasyonları. In: Tabak F, Balık I, Tekeli E, editors. Viral Hepatit. Istanbul: Viral Hepatit Savaşım Derneği; 2005; pp. 170-174.

3. Alberti A, Vario A, Ferrari A, Pistis R. Review article: chronic hepatitis C-natural history and cofactors. Aliment Pharmacol Ther. 2005;22:74-78.

4. Wong T, Lee SS. Hepatitis C: a review for primary care physicians, CMAJ 2006;174:649-659.

5. Akarca U, Balık I, Örmeci N, Tabak F. Hepatit C Enfeksiyonunda Tanı ve Tedavi. Viral Hepatit Dergisi. 2011;17:117-126.

6. Strader DB, Wright T, Thomas DL, Seeff LB. American Association for the Study of Liver Diseases. Diagnosis, management, and treatment of hepatitis C. Hepatolog. 2004;39:1147-1171.

7. Manns MP, Pockros PJ, Norkrans G, Smith $\mathrm{Cl}$, Morgan TR, Häussinger $D$, Shiffman ML, Hadziyannis SJ, Schmidt WN, Jacobson IM, Bárcena R, Schiff ER, Shaikh OS, Bacon B, Marcellin P, Deng W, Esteban-Mur R, Poynard T, Pedicone LD, Brass CA, Albrecht JK, Gordon SC. Long-term clearance of hepatitis $C$ virüs following interferon-2b or peginterferon-2b, alone or in combination with ribavirin. J Viral Hepat. 2013;20:524-529.

8. Veldt BJ, Heathcote EJ, Wedemeyer H, Reichen J, Hofmann WP, Zeuzem S, Manns MP, Hansen BE, Schalm SW, Janssen HL Sustained virologic response and clinical outcomes in patients with chronic hepatitis $\mathrm{C}$ and advanced fibrosis. Ann Intern Med. 2007; 147:677-684.

9. Cardoso AC, Moucari R, Figueiredo-Mendes C, Ripault MP, Giuily N, Castelnau C, Boyer N, Asselah T, Martinot-Peignoux M, Maylin $\mathrm{S}$, Carvalho-Filho RJ, Valla D, Bedossa P, Marcellin P. Impact of peginterferon and ribavirin therapy on hepatocellular carcinoma: Incidence and survival in hepatitis C patients with advanced fibrosis. J Hepatol. 2010;52:652-657.

10. van der Meer AJ, Wedemeyer H, Feld JJ, Hansen BE, Manns MP, Zeuzem S, Janssen HL. Is there sufficient evidence to recommend antiviral therapy in hepatitis C? J Hepatol. 2014;60:191-196.

11. Ogawa E, Furusyo $N$, Kajiwara E, Takahashi $K$, Nomura $H$, Maruyama T, Tanabe Y, Satoh T, Nakamuta M, Kotoh K, Azuma K, Dohmen K, Shimoda S, Hayashi J; Kyushu University Liver Disease Study (KULDS) Group. Efficacy of pegylated interferon alpha- $2 \mathrm{~b}$ and ribavirin treatment on the risk of hepatocellular carcinoma in patients with chronic hepatitis C: a prospective, multicenter study. J Hepatol. 2013;58:495-501.

12. van der Meer AJ, Veldt BJ, Feld JJ, Wedemeyer H, Dufour JF, Lammert F, Duarte-Rojo A, Heathcote EJ, Manns MP, Kuske L, Zeuzem S, Hofmann WP, de Knegt RJ, Hansen BE, Janssen HL. Association between sustained virological response and all-cause mortality among patients with chronic hepatitis $\mathrm{C}$ and advanced hepatic fibrosis. JAMA. 2012;308:2584-2593.

13. Juanbeltz R, Goñi Esarte S, Úriz-Otano JI, Martínez Echeverría A, Elizalde I, Zozaya JM, Castilla J, San Miguel R. Safety of oral direct acting antiviral regimens for chronic hepatitis $C$ in real life conditions. Postgrad Med. 2017;129:476-483.

14. Colombo MG, Weiland O, Cohen DE, Du Four JF, Reynaert H, Diago M, Villa E, Cercel AS, Xie W, Enejosa JV, Coakley E, Trinh R, Podsadecki T. SVR12 rate of $98.6 \%$ in $992 \mathrm{HCV}$ genotype 1b-infected patients treated with ABT-450/r/ ombitasvir and dasabuvir with or without ribavirin. Hepatology. 2014;60(Supp):1131A.

15. Lawitz E, Poordad FF, Pang PS, Hyland RH, Ding X, Mo H, Symonds WT, McHutchison JG, Membreno FE. Sofosbuvir and ledipasvir fixed-dose combination with and without ribavirin in treatmentnaive and previously treated patients with genotype 1 hepatitis $C$ virus infection (LONESTAR): an open-label, randomised, phase 2 trial. Lancet. 2014;383:515-523.

16. Calleja JL, Crespo J, Rincón $D$, Ruiz-Antorán B, Fernandez I, Perelló C, Gea F, Lens S, García-Samaniego J, Sacristán B, García-Eliz M, 
Llerena S, Pascasio JM, Turnes J, Torras X, Morillas RM, Llaneras J, Serra MA, Diago M, Rodriguez CF, Ampuero J, Jorquera F, Simon MA, Arenas J, Navascues CA, Bañares R, Muñoz R, Albillos A, Mariño Z; Spanish Group for the Study of the Use of Direct-acting Drugs Hepatitis C Collaborating Group. Effectiveness, safety and clinical outcomes of direct-acting antiviral therapy in HCV genotype 1 infection: Results from a Spanish real-world cohort. J Hepatol. 2017;66:1138-1148.

17. Backus LI, Belperio PS, Shahoumian TA, Loomis TP, Mole LA Comparative effectiveness of ledipasvir/sofosbuvir \pm ribavirin vs. ombitasvir / paritaprevir / ritonavir + dasabuvir \pm ribavirin in 6961 genotype 1 patients treated in routine medical practice. Aliment Pharmacol Ther. 2016;44:400-410.

18. Backus LI, Belperio PS, Shahoumian TA, Loomis TP, Mole LA. Real World effectiveness of ledipasvir/sofosbuvir in 4365 treatmentnaïve genotype 1 hepatitis $C$ infected patients. Hepatology. 2016:64:405-414.

19. Ioannou GN, Beste LA, Chang MF, Green PK, Lowy E, Tsui JI, Su F, Berry K. Effectiveness of Sofosbuvir, Ledipasvir/Sofosbuvir, or Paritaprevir / Ritonavir / Ombitasvir and Dasabuvir Regimens for Treatment of Patients With Hepatitis C in the Veterans Affairs National Health Care System. Gastroenterology. 2016;151:457471.

20. Rodríguez-Osorio I, Cid P, Morano L, Castro Á, Suárez M, Delgado M, Margusino L, Meijide H, Pernas B, Tabernilla A, Pedreira JD, Mena Á, Poveda E. Real life experience with direct-acting antivirals agents against hepatitis $C$ infection in elderly patients. $J$ Clin Virol. 2017;88:58-61.

21. Welzel TM, Hinrichsen $H$, Sarrazin $C$, Buggisch $P$, Baumgarten $A$, Christensen S, Berg T, Mauss S, Teuber G, Stein K, Deterding K, van Bömmel F, Heyne R, John C, Zimmermann T, Lutz T, Schott E, Hettinger J, Kleine H, König B, Hüppe D, Wedemeyer H. Realworld experience with the all-oral, interferon-free regimen of ombitasvir/paritaprevir/ritonavir and dasabuvir for the treatment of chronic hepatitis C virus infection in the German Hepatitis C Registry. J Viral Hepat. 2017;24:840-849. 